\title{
HISTOPATHOLOGICAL STUDY OF CHRONIC SINUSITIS IN THE SCHOOL CHILDREN.
}

\author{
By \\ K. KATO \\ From the Department of Otolaryngology, Faculty of Medicine Shinshu University, Matsumoto \\ (Director: Prof. T, Suzuki) \\ One hundred cases of chronic sinusitis, aged 6 to 15 , were examined and histopathological \\ study of the mucosa of the sinuses was made. Edema of the mucosa was much more remarkable \\ than in adults, probally due to the exudative diathesis, which is common in children. No remar- \\ kable vascular change in lamina propria was observed and this was thought to be responsible \\ for the spontaneous healing of the disease in children,
}

\section{小児慢性副鼻腔炎の病理組織学的研究}

\section{信州太学医学部耳算咽崌科学教室（主任：鈴木篤期教授）}

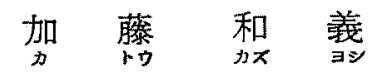

i. 緒言

2. 钼察材料及び方法

3. 成績及び务察

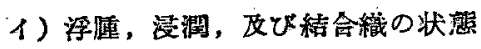

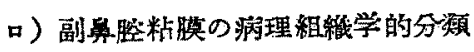

附）上顠洞客穔と粘膜湖型との関保

八)上皮の麦化

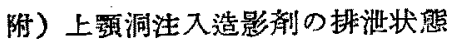

））被覆上皮基底膜の媇化

ホ）腺租織の状熊

附) 副鲜腔附澧汗について

一）血管の数化

4. 綜 括

5. 結 語

\section{1. 緒 言}

小垐の副鼻腔炎の存在は古くから病理学的方面の検索

Kよって知られて括り，Harke (1895) は小児 394 例

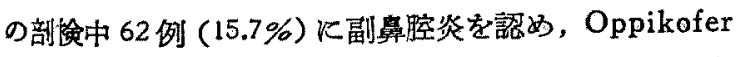
2) 4小昌屍体のうち1才〜20 才の るのに $62.5 \%$ の副悬 瞪炎の存在を認めたが，1920 年以降になつてよ5やく
小児慢性副䀘腔炎の研究は進展してきたように思われ る.しかしその病理組織学的研究は比較的少いようであ る. Dean 3) 4), Carmack 5), Spielberg 6), Mensing 7), 等の記載があり，我国においては名越本び三沢 ${ }^{25)}$ ，白

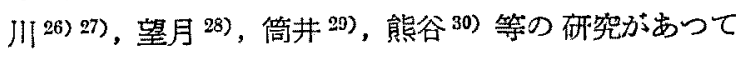
その状態が次第に明がされてきたが，大体に执いてそ の病理組織学的所見は Hajek ${ }^{8)}$, Oppikofer ${ }^{2)}$, Mannasse 9), Nuhsmann 10), Mullin and Ball 11), 後藤 ${ }^{31)}$, 片岡 ${ }^{32)}$, 姜 ${ }^{33)}$, 吉野 ${ }^{34}$ ), 菊地 ${ }^{35)}$, 白川 ${ }^{27)}$ 等の研究化 よる成人のそれと大差はないよであるが，病変は比較 的新しく又所謂アレルギー性変化と云うことが幾分強調 されているようである・

私は教室に括ける小兄慢性副鼻腔炎硎究の一環として 本症の病理組織学的所見について検討を加えたのでここ に記戴し御批判を仰ぐ㳄第である。

\section{2. 観察材料及び方法}

長野県松本市近效の小学校 3 校, 中学茭 2 校を対标々 して定期的耳鼻咽啖科検誩を行い，少くとも二年連続慢 忙副鼻腔炎と診断されたものより手術適応者を選出し， 昭和 30 年 7 月以降上り昭和 31 年 8 月に至る 迄の期間 そ，6才〜15才迄の 100 例 200 側の副鼻腔根治手術を施 
行，乙の際採取した副鼻腔粘膜標本は第 1 表の如くであ

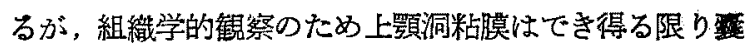
状に採取し不可能な場合には聰門部，洞底部粘膜を区別 して採取した．これ等骠本は10\%ホルマリン水溶液に て固定し，バラフイン包埋を行いいマトキシリンエオジ 之重染色，P. A. S. 染色，線維素染色，及びその主な るものについてワンギーソン染色, マロリ一染色, 鍍銀 染色を行い詳細に検鏡した・上筼洞容積の計測は洞粘膜 を剝離除去し充分止血した後，犬药䈑開空部を汪ら水平 位に保ら $20 \mathrm{cc}$ 注射器により減菌蒸溜水を上顎洞に过か に灌注し洞内を充満したときの注入量をもつて表した。 この際注入蒸溜水が鼻腔内に流出するのを防止するため 中鼻道はガーゼタンポンにより閉鎮した・な拓術前に括 いて 69 例 69 側の上䫑洞に 20\% モルョドールを注入し その排沺状態を観察した.

第 1 表 手衍例数，探取粘膜標本数

\begin{tabular}{|l|lllllllllll|}
\hline $\begin{array}{l}\text { 年 } \\
\text { 令 }\end{array}$ & 6 & 7 & 8 & 9 & 10 & 11 & 12 & 13 & 14 & 15 \\
\hline $\begin{array}{l}\text { 例 } \\
\text { 数 }\end{array}$ & 1 & 4 & 9 & 4 & 5 & 16 & 18 & 10 & 20 & 3 \\
\hline
\end{tabular}

\begin{tabular}{|c|ccc|}
\hline & 不 & 左 & 計(側 \\
\hline 上預洞 & 98 & 97 & 195 \\
聰门部 & 95 & 98 & 193 \\
篩骨洞 & 91 & 95 & 186 \\
\hline
\end{tabular}

\section{3. 成績及び考察}

日常臨床に括いて屡々遭遇する奻小児の副鼻腔炎の存 在は前述の如く病理学的に又臨床的に 検索されている

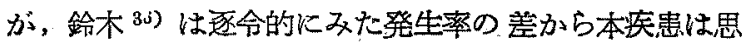
春期又はそれ以後に打いて初発するより遥かに多い数が 自然に治癒するか，少くとも潜在的になつてしま5むの と推測しうると述べており，Birrell 12） る思春期炕至つ て自然によくなつてくるだらうと云つているが，かつる 自然治丞の傾向を示す小览副鼻腔炎の粘膜病理組織所見 ふ今まで発表されてきた成人のそれと奎があるがう か, 又その病変の状態について観察してみたいと思5。

\section{1）浮婳, 浸潤及び結合織の状態}

浮腫一般的に粘膜浅層部に高度で，腺層骨膜層に至 る粘膜梁圆部ではその程度を減じている・浮腫高度のも のは結合織線維は大きな繹眼状学呈し(附図 1)，又蜂菓
の目様な状態を呈するむのはその間覙に㞗々エオジンに 淡染する治出液と思われる凝固物を認める。これは多く 細胞浸潤の強い所火みられる・組織の絀状粗彭化を示す むの H (高度)，組織及び浸潤細胞の粗鬆化のみとめら れるるの十(軽度)，その中間程度をH(中等度）とし て年令別に観察すると第 2 表示す如くで，上顎洞及び 篩骨洞でも浮腪の程度は年令的に有意の至はない。たら

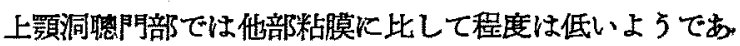
る。

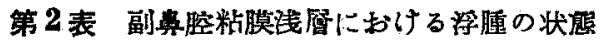

\begin{tabular}{|c|c|c|c|}
\hline ja & 上䫚洞 & 聭门部 & 箷 骨 洞 \\
\hline & $\pm+H$ & $\pm+4+4$ & $\pm+t+1$ \\
\hline (10倠) & $\begin{array}{llll}3 & 2 & 4 & 7\end{array}$ & $30^{2} 52$ & \\
\hline $8 \approx 9$ & 8683 & $(250) 18$ & $(24) 9$ \\
\hline $\begin{array}{l}10=11 \\
(42 \pi)\end{array}$ & 17274 & $(4 \%) 237$ & $(399)^{73} 12$ \\
\hline $\begin{array}{l}72 \approx 3 \\
(73 n)\end{array}$ & 23287111 & $(24) \mid 3927$ & $(00))^{3}$ \\
\hline $\begin{array}{l}14 \sim 5 \\
(454)\end{array}$ & 16785 & $\left|\left(44^{*}\right)\right| 30$ & $(430)^{20} 17$ \\
\hline 柿 & 6475 32 24 & 798216363 & 78 \\
\hline
\end{tabular}

一般に副鼻腔炎粘膜固有層において浮透は殆んどすべ ての場合にみとめられるものであるが，Eggston 13) は 反復する感染によって結局は Periphlebitis, Perilym-

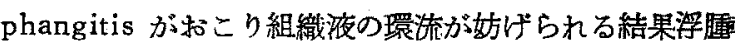
が抗こるといいPolypoid sinusitis の原因としている が，Menkin 14) b炎定はまず毛細脈管に和ける体液交 流の障害をるつて始り，炎症局所では毛細血管の正常な

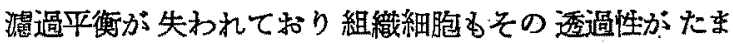
り，細胞内液が細胞外え透するので，毛細血管周囲組 織は血管と傷害細胞とから洷透した液でみたされるよう になると云ってをり，要するに炎症局所の浮腫の発現は 局所の血管反応が重要な役割をなすものであるが，天野 3i) は炎症に和いて最もよく反応する間葉組織の中で活 潑に反応するるのは血管であると云い，刺战の倳式，副 筒亦ルモン等はこれを修飾するものであると云つてい る.

Hansel 15)，名越 ${ }^{55)}$, 白川等は比較的高度の浮腫を厂 レルギー反応によるとしてをり，小罗においてかかる場 合が多いと云われているが，網眼状を呈した高度浮国盾に ついて私の観祭では，成人に和ける片岡の 43 例中 7 例， 西端38）の63例中 8例と大差はないが，全般的にみる そ浮腫性変化は成人に比して一般に 目立っようである （西端及び横出は䯩度から判然せ双程度のるのまで 40 \% (63 例中) と記しているのに対し, 私の場合は軽度以 上のものが $67 \%$ (159 側吅) であつた)：これは焱泟が 
なお新しいと推察され，又小肾一般の特貿として考兄ら れる出性素質 ${ }^{39}$ ) (小昌期に汇強く現れ 思春期以降は 減少する）によって影響されている結果と考党られる。

浮腫は粘臊浅層に強いと云うことに対して吉野 34)は， 上皮下層には終末血管網を作つているためだと云つてい ることは前述の考えからうなずけることである：白川 27) は細菌性アレルギーによる浮腫については組織内の

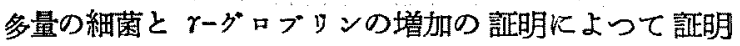
できるし，出液はェォジンにて淡染L P.A. S. 陽 性物質であると云つて和り, Hansel 15) はアレルギー性 のときは上皮直下に現れること多く，細菌性アレルギー のときは細胞浸潤のある場所ではいずれの部です発現し らると述へているが，私の場合に执いても浸潤の多い粘

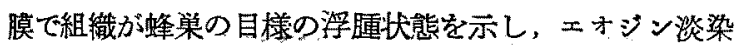
の物質をみたような場所は恐らくかかる範㹗に属するも ののよ5に思われる。

浸潤 浮腫の 場合と同様に 粘膜固有㬝の 浅層部に 強 く，梁層部になるにつれて軽度となるが血管，腺の周囲 には浸潤の比較的著明にみられる例があつた・高度細胞 浸潤のものでは被罂上皮の基底膜層を通過して上皮層に

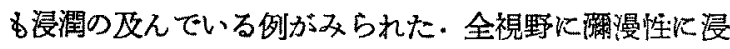
潤の文んでいるすの卅（高度）(附図2）としこれを基 準にして H (中等度)，十 (軽底)をきめて観祭すると 第了表の如くで，年令的に浸潤程度に有意の美は認めら れない，篩骨洞粘膜では上顎洞粘膜に比して浸潤は著明 には㲈められない。

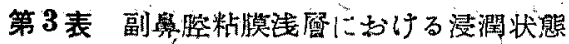

\begin{tabular}{|c|c|c|c|}
\hline & 上䪽洞 & 聭门：部 & 篰 骨 洞 \\
\hline 令 & $\overline{ \pm}++4$ & $T+H+H$ & $\bar{t}+H+4$ \\
\hline (100) & $2 \quad 8$ & 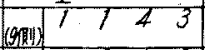 & 5331 \\
\hline$\frac{1729}{825 n)}$ & 1078 & 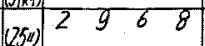 & (24) $3 \begin{array}{lll}3 & 16 & 5\end{array}$ \\
\hline 14211 & 391278 & $(414) ? \begin{array}{llll}76 & 9 & 9\end{array}$ & 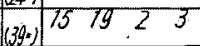 \\
\hline$(72)$ & 72202021 & 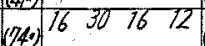 & $(0(0))$ \\
\hline $\begin{array}{l}7275 \\
\left(45^{n}\right)\end{array}$ & 8131311 & $(44))^{820115}$ & $(43))\left(\begin{array}{llll}17 & 78 & 6 & 2\end{array}\right.$ \\
\hline 計 $(\%)$ & 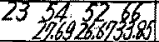 & $347646 \quad 37$ & 5999199 \\
\hline
\end{tabular}

浸潤細胞の種類は各粘膜を通じて一般に淋巴球最も多 く，次いで組織球，形資細胞，好酸球，好中球つ順でそ の他ラッセル小体，硝子球，へモジデทンを喰食した細 胞等が観察された・各粘膜に括ける主な細胞の浸潤程度 は第 4 表に示す如くである。淋巴球つ限局性に集合した

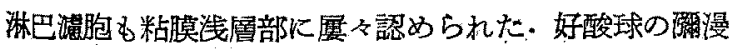
性にあるいは集筷性に浸潤して，美麗な像を呈するむの

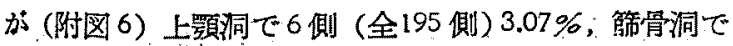

2 側 (全186 側) $1.07 \%$ Kみられ，左右側一致して美麗 像を呈したるのは1 例のみであらた. 又形躓細胞の集簇 性に浸潤しているものが上顎洞に执いて一側みられた。 細胞浸潤は一般に急性期に衫いては好中球が主体である が，炎症が慢性化すると炎症局所は単核性喰食細胞，好 酸球，淋巴球，形質細胞の演潤が現れると考えられる が，好中球の浸潤は少く，や」著明にみられるものは上 額洞で 1 側のみで軽底つものは7 側であつたが，片岡 32)，姜 33)，西端 38)，吉野 37) む好中球灵潤の少いことを 述べている.このことは吉野の云 弓如く急性堌悪に括い て組織内に浸潤して子比較的早く粘膜外飞游出乙鼻汁中 に出るものか，又好中球浸潤を示すほどの急性状態の少 いことかであろう・

第 4 表 浸潤細胞種類

\begin{tabular}{|c|c|c|}
\hline 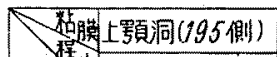 & 聰门部 (193側) & 䇛 骨洞U86溉 \\
\hline 類度 & $\pm+H$ & $\pm+T$ \\
\hline 中球 787 & 197 & 100 \\
\hline 酸球 165243 & 1622452 & 1779 \\
\hline 729 & $438848 \quad 14$ & 788916 \\
\hline 糡球 7186275 & 136543 & $16618 \cdot 2$ \\
\hline 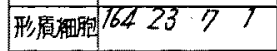 & 179722 & 7815 \\
\hline
\end{tabular}

淋巴球の浸潤は前述の如く高度であつたが，西端は殆 んと認めさるものは7 洞 (197. 例中) の及と述べている.

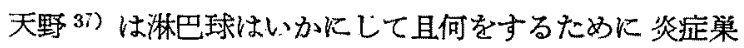
に現れてくるかは不明であると述べ，古る種つ刺战が淋 巴球の集簇に適していると考文得るとい〉，結局高度り ンハ球曼潤がみとめられるに拘らずその意義については 明膫ではないが，坂井 55) むいつている如く淋巴球つ結 節状策簇と共に慢性炎症状態の特長だと思われる。

組織球瑐述のよ5に淋巴球に次いで多くみとめられ た.片岡も比較的多〈認められるとい〉, 姜はや〉高度 発現するもの10洞 (全197洞)，軽度に発現するもの 86 洞であると云っているのに対し私の場合も大坴なく，上 顎洞 195 側中軽度 62 側, 中等度 15 側であつた. この細 胞の喰食機能について西端は発病年数つ短いものほど機 能は正盛で，実験的感染に括いて急性期に組織球の喰食 機能が旺盛で慢性に移行するにつれて機能淢退をみるよ らであつたと述へているが，年令別にみた組織球の漫潤 度は大差なからたが10〜11才に抏いてや〉高いように 思われた. 天野 37) は組織球に䦎連して次の上5に述心 ている即ち炎症火和いて好中球症反店が尔こるとか，あ るいは組織球性反応を起すとか云うことは血管反応が主 
体であるかあるい組織珷活性反沁が主体であるかつ の極端を現すとすぎないと。

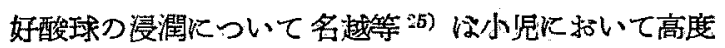
の浮腫を半い著明な好酸球浸潤を示した症例は14 例中 9 例に観祭されたと述へ，これをアいルギーに上るるの だろらといっている。

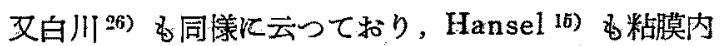
に本細胞の出現すること粱腫についでアレルギー㭠特 徵としている. 更に Coates, Ersner ${ }^{16)}$, Weille ${ }^{17)}$ る アレルギーに括りる好酸球つ浸潤を強調しているが，

Kline ${ }^{18)}$ は好酸球つ出現について時間的に 差の方こ とを述べ，武田 ${ }^{4 n)}$ はアレルギー性組織变化に一致する 病変が存するとしてる直ちにこれをアレッギー炎症と云 らことは不可能であると同時炕，フレルギーとしての基 本的変化が現れないとしても广レルギー反忘の本質がか くされていることがあると云い，前川21 は所謂アレル ギーの組織学的規定はできないと述べているが，結局ア レルギーが関係しているかどらかは個々の場合について 臨床的な面からむ同時に桧討し，発病経過期間について も考瑠して組䅧所見が観察されねばならないと思われ る. 管井 29）はかかる立場より検討して好酸球の高度出 現はアレルギー素因特に遗伝的素因に密に関係があると 述べた・私の標本からは著明漫潤は箭述の如く6剆 3.07 \%で吉野等の記載している成人の場合と大盖なく，名越 等のように高率にはみられなからた。

形質細胞沉ついて片風は淋巴球に比適するほど著明に みられ，最京度にみられるるのは9例(全43例)であ つたといい，姜も最も多量に浸溜する細胞であると述べ 本細胞の発現を及ない例は殆んどないようであると云つ ている・西端は本細胞は細胞浸潤の主成分をなすと云つ ているが，私のみた例ではその浸潤度は低く溯漫性儿密 等して観察されたものは上顎洞にて1 側（全195 側）の みであつた・本細胞は一般に慢性炎症に現れるとされて いるが，その害義炕ついて天野は抗体産生系の主たるる のであるとしている・

結合織 これむ慢性副鼻腔炎の病理組織に重要な无子 であろう・全骠本を通擥してその程度を州(高度)，H (中等度，附図3），十(軽度)飞大別してみると浮連, 漫 潤とは逆に腺層，骨膜層と粘膜の深買になるにつれてそ

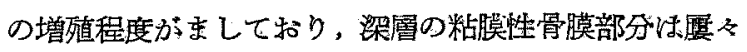
肥存がむり線維莱細胞が著明に増殖している゙例がみられ た・上顎洞聰門部では細胞に之しい陳旧な結合織が他部 粘膜に比して多く，節骨洞粘膜でば䠌猚事䋨胞多く比較
的新しい結合織が多かつた（第 5 表). 各部の粘膜につ いて年令別にみると第6表炕示す如くで，上筼洞及ひ上 靧洞聰門部ては年令の長ずるにつれて増殖が強い上うで

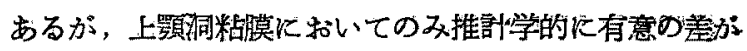
みられた（P<0.05）。堌殖は婘門部火最る強い上5に観 察された。

第 5 表 新しい結合織と陳旧な結合織

\begin{tabular}{|c|c|c|c|}
\hline & 上㯰洞 & 聰门部 & 箷 骨洞 \\
\hline 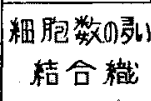 & $\begin{array}{l}134 \\
\text { (側) }\end{array}$ & 98 & 138 \\
\hline 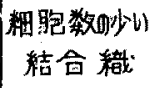 & 55 & 90 & $\theta$ \\
\hline
\end{tabular}

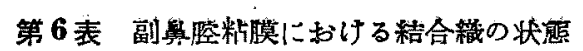

\begin{tabular}{|c|c|c|c|}
\hline 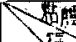 & E額 洞 & 渞门部 & 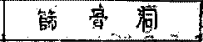 \\
\hline 年令 & $\bar{I}+H+H$ & $I+H+H$ & $\frac{3}{ \pm}+H$ \\
\hline $60 \%$ & 772 & \begin{tabular}{|l|llll|}
$\left(g_{4} \mid I_{5}\right)$ & 1 & 4 & 3 & 7
\end{tabular} & 7 \\
\hline$(25 \cdots)$ & 210103 & 72112 & $(240)^{15}$ \\
\hline (4) & 115224 & $\left(44^{4}\right) \mid \begin{array}{llll}12 & 12 & 21 & 7\end{array}$ & $(39 \%) 17174$ \\
\hline 12233 & 12272713 & $(24 *)^{4} \quad 20 \quad 33 \quad 17$ & $(70 *)^{30} 328$ \\
\hline 425 & 2112012 & $(44) 101915$ & $\left.\left(43^{3}\right)\right]$ \\
\hline 計 & 78707532 & 6588742 & 7980 \\
\hline
\end{tabular}

西端 ${ }^{38)}$ は生来粘膜素資として結合織に富んでいる埸 合も考えられるが，本症にみられる古い䊅合織即ち結合 織線䧽い上前あつた焱症の印とみられる。それ故新しい 結合織は現在か最近の炎症の印とみるべきであると云つ ている. 更に体質によって炎症に対する結合織増殖と云 う反心は著しく異るとる述へているがこのことに関連し て阿部 ${ }^{43)}$ ，车田 ${ }^{24)}$ は副鼻膑う Pneumatisation 々粘 膜病変について研究している.

以上の如く結合織増殖には種々な要素が関俰するよ5 であるが，姜は次のよう記している・上皮下゙の浅層て は最も高度なるもの3洞 (全197洞), や上高度なるの 31 洞, 中等度 82 洞，軽度 81 洞，粘膜下伩び骨膜層で は高度なもの50洞，中等度なもの97洞，軽度なるの

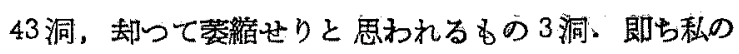
検索例では，上顎洞粘膜て浅層ては高度（卅）なるのな

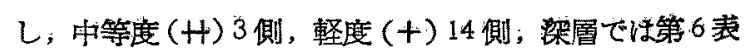
に录す如くで，このよ5に成人の場合より岁增殖が少い ことは资症の面からのみでなく，小児と云う年令手考慮

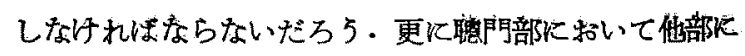
比して結合織の増殖が強いように観察されたことも，本 来をの部では粘膜が厚いと云うことを考えなければなら 


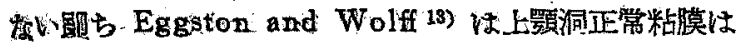

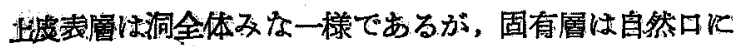
近さくほど厚くなると云い Cutore 19》も最む嘁いのは 昇腔側であると云つている。

節骨洞では前述の如く線維若細胞堌殖が目立つようで あるが，上碞洞では浸潤の強い粘膜に挌いてその程度は 低下している.富困 ${ }^{22)}$ 《比較的軽度の障害の加わる場

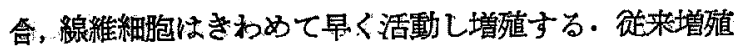

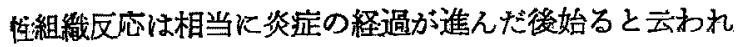
ているが刺战の種類を吟味すれば早期火起る現象である ことがわかるといい, Menkin 14) む傷害組織の修復は すで急恎炎症の経過中炲つている：修復反応が资症 の比㜞的末期に起つているよ5な場合には，炎症局所に 学核制哙食細胞，好酸球，ソンハ球，形質細胞の浸潤と 期化種々校程度の線䊒化がみとめられ，この組織像は通

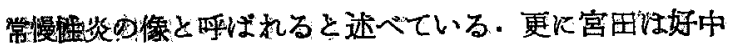
球め游出㽗出性や〉おくれて繁殖反応の経過の間に現

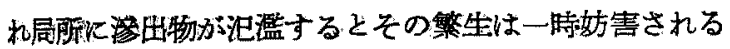
と述へている・これらの考方方をすれば䇫骨洞火和いて は，上颚洞に比して刺战感染程度が弱いために病変の程 度も少く，線維莱細胞の堌殖が著明に現れ防衛反応が行 われていると理解しうるように思劣る・しかしかかる意 味の線䊒の増殖も色々な条件飞上つて影響をうけるるの

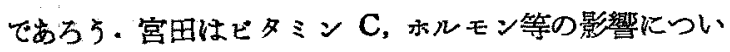
て述べてる。

\section{口) 副鼻腔粘膜の病理組織学的分類}

附）上頭洞容積と粘膜病型との関你

副鼻胵炎粘膜の病理組織学的分類は多くの研究者によ って行われてきたが，Oppikofer 2 も云つているよう に一洞粘膜のうちに一組織型のみに属する所見を呈する むのなく，その多様性のために研究者独自の立場から

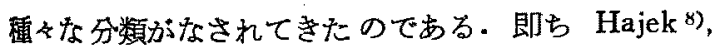
Mannasse 9), Nuhsmann ${ }^{10)}$, Schall ${ }^{20)}$, Eggston and Wolff 13), Hansel 15) 等の記載があり, 後藤 ${ }^{31)} は \mathrm{Ma}$ nnasse の浮腄型, 浸潤型, 線維型の分颣混合型を加 兄た. 西端 38) は横出の膠様型, 線維型, 浸濯型, 浮鄅 型，乳樣型，腺型，滲出型の分類について実際ではこれ らの型が 混合してきて非常に多くの 分類になつたと述 ベそれ故吉村教授が恐らくこれらの炎症型なるものは 固定したものではなくて，炎症機较のPhase に過ぎな

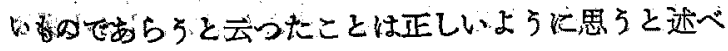
ている. 結局炎症洼動的な過程であつて静止した状態で はない云らことから，炎症と云う流れの中で变化する
粘膜形龍像の代表的なものをるつて分類せざるを得ない ように思われる・即ち前述の三つの变化を中心とした Mannasse 9) の浮腫型, 浸潤型, 線維型, がからる考 方洱適切のように思われる。つまり Menkin ${ }^{14)}$ の云 弓炎症の基本形式にしたがうと，(1) 炎正は先ず毛細脈 管の体液交流の障害をむつて始り浮䐈が発生寸る(浮腫 型)・(2) 炎症が進むにつれて 細胞浸潤がおこる（浸潤 型). (3) 炎症火よる賃害の悠復は線維若細胞, 結合織 増殖によって行われるようとなる(線維型).これらの 基本型の間に吉野も分類しているように混合型が存在し てくる・即ち

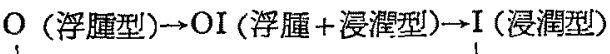

$$
\begin{aligned}
& \text { FO (浮腫十線維型 }) \mathrm{F}(\text { 線維型 }) \leftarrow I \frac{1}{\mathrm{~F}}(\text { 浸潤十線維型 }) \text {, } \\
& \text { N (正常型)；病変が軽度で正常に近いと思われる } \\
& \text { छの }
\end{aligned}
$$

となる、以上の分類以よって病型を分けると第 7 表, 第 1 図の如くになり上矤洞聰門部粘膜は線䊒化を中心とし た病型が多く，節骨洞粘膜では浸潤型が少く浮腫型，線 維型が同程度に多くみられた・更に笁骨洞では正常型が 54 側（全 186 側)に認められた。吉野の研究による成人， の場合と比較すると第 1 眓の如くで上頑洞について成人 より浮運型が多く，線稚型がや」少いことは炎症が成人

\begin{tabular}{|c|c|c|c|c|c|}
\hline & & 001117 & 10 & & \\
\hline & & $\begin{array}{llll}7 & 2 & 5 & 7\end{array}$ & 7 & & 10 \\
\hline & 9 & $\begin{array}{lllll}3 & 8 & 5 & 7 & 1\end{array}$ & 1 & & 2 \\
\hline & $0 \sim 7$ & 3711136 & 2 & & 42 \\
\hline & -13 & 131172411 & 6 & & $\pi$ \\
\hline & 15 & 432218 & 6 & 1 & 4 \\
\hline & & $2313066 \quad 26$ & 676 & 2 & 179 \\
\hline & 7 & 22332 & & & \\
\hline & 9 & 11176 & & & 2. \\
\hline & 10,71 & 2581312 & 21 & & 4 \\
\hline & $12 \sim 3$ & 372302 & 56 & & 72 \\
\hline & $14 \sim 15$ & 421142 & 17 & 7 & 4 \\
\hline & & 917246766 & 68 & & 19 \\
\hline & $6 \sim 7$ & 73 & & & \\
\hline & $8 \sim 9$ & 6442 & & & 12 \\
\hline & $10 \sim 11$ & 97227 & 73 & & 3 \\
\hline & $12 \sim 3$ & 1152510 & 67 & & \\
\hline & $14 \sim 75$ & 74331 & 22 & & 4 \\
\hline & & 37201215 & & & \\
\hline
\end{tabular}
に比して新しいのではないかと思われる・籍骨洞におい。

第 7 表，副然腔竾粘膜病型 
て浸潤型が少く浮腫型, 線維型が目立つ点は成人に括け ると同様で強い感染刺㦸が少い結果と推祭される。な 線維型のものでは一般に粘膜は厚さを減じ素縮状態のよ う火みられたものもあり，部分とよっては粘膜上皮層が 楩没して四窝を形成している（附図 4）のが観察され， 粘膜の波状々態の天居めに腺排泄管の蛇行（附図 5) がみ られた。

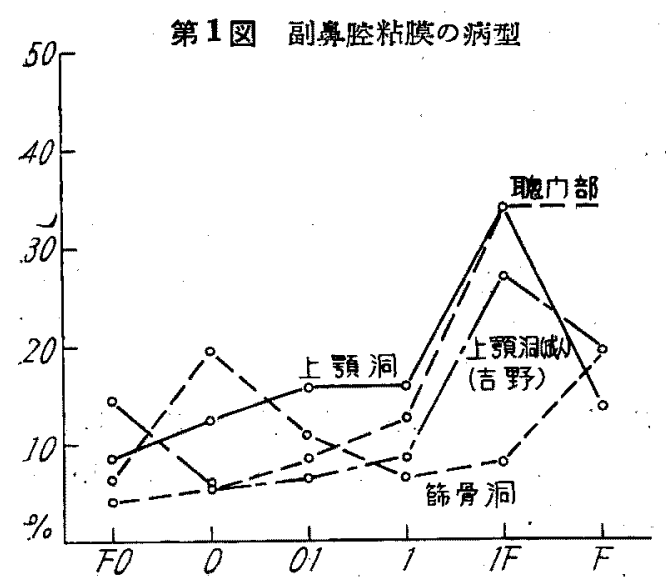

附）上顎洞容積と粘膜病型との関保

以上の如き基本的な反応形式を修飾すると考光られる るの，所謂アレルギ一反応，出性素質，局所の粘膜 素質，全身状態，栄盖等があげられる.阿部 23)，牟田 22) は成人副鼻腔の容積の発育良好なるものから抑制型に及 ら行い，粘膜病型は浮腫性より線維性を主とするるの 光推移すると述へて，Pneumatisation 型式火より獲得 された局所体質的因子がその炎症型式に，重要な影響を 結果することは否み得ない所であると云つているが，私 は野村 25) の記載している上顎洞容積の 平均值を基準に して，8cc 以下，9１1cc，11 cc 以上飞分類した結果は

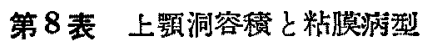

\begin{tabular}{|c|c|c|}
\hline 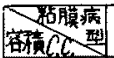 & 0011 IF F FON & \\
\hline 8以下 & 4121132116 & 76 \\
\hline $9 \sim 11$ & 59987144 & \\
\hline 17 以上 & 75101021116 & 75 \\
\hline & 2431 & \\
\hline
\end{tabular}

第8表の如くで，浮腫型では $11 \mathrm{cc}$. 以上の発育良好と思 われるむのが多くみられたが，線維型では８cc 以下の 発育不良と考光られるものる，11cc 以上の発育良好と 洘えられるものも同程度にみられた。つまり登育不良と
思われるむのでは明に線維型が多いと云えるが，発育良 好と考党られるるのは浮隀型が多くて線維型が少い:をは 云えないような結果炈なな。

\section{八）上皮の変化}

附）上頻洞注入造影绡刂门排泄状態

粘膜上皮は全部剝離してみられない場合も岕つたが， 西端, 白川2i), Anderson 21) る云つている如くぞの織 細さのために損傷することなしに標本を作成することは 困難であるらとと思われる。

剩離脱落 程度の差はあるが殆んどの標本化 みられ る，高度のむのでは基底膜が 裸出しているすのむり 所をまだらに上皮細胞の存在している例すあうた。第 9 表炕示す如く聰門部粘膜で剝脱は比較的強いようであ る・得脱は上皮病変中最も顕著なもののようであるがこ れは機械的な損傷によるものが大いに考えられる。名越 25) はアレルギーの場合は上皮細胞個々の 膨状浮腫が主 変化で肥厚の強く括こらない5ちに剝脱の傾向があると 云われるが，現れた変化のみから刺战の性質を断定する ことはできないと云つている。

第9表上皮の病变

\begin{tabular}{|c|c|c|c|c|}
\hline & 利 脱 & 增 殖 & 杯稩，胞 & 稚 \\
\hline & $\pm+H+H$ & $\bar{I}+H+H$ & $I+H+H$ & \\
\hline & $\begin{array}{lll}4 & 3 & 3\end{array}$ & \begin{tabular}{|l|}
73 \\
\end{tabular} & $\begin{array}{ll}97 \\
9\end{array}$ & \\
\hline & $\begin{array}{llll}5 & 5 & 10 & 4\end{array}$ & 17.7 & 213 & 7 \\
\hline & $\begin{array}{lllll}3 & 12 & 13 & 111\end{array}$ & 2811 & 38 & 1 \\
\hline & $13 \quad 27 \quad 1312$ & $\begin{array}{lll}38 & 26 & 1\end{array}$ & 549.2 & 1 \\
\hline & $\begin{array}{llll}8 & 8 & 17 & 10\end{array}$ & 2775.7 & $384 \%$ & \\
\hline & $2956 \quad 56 \quad 4896$ & $77 \% .62 .2$ & 160174 & 2,560 \\
\hline & 162 & 72 & 9 & \\
\hline & 27106 & 2041 & 25 & 7 \\
\hline & $\begin{array}{llll}2 & 8 & 11 & 14\end{array}$ & $24 \mathrm{ll}$ & 313 & \\
\hline & $420 \cdot 1924$ & 4027 & 643 & 2 \\
\hline & $31214 / 2$ & 3110 & 391 & \\
\hline & 71486058 & 72254 & 1687 & 3n \\
\hline 100 & 2347 & 181 & 73 & \\
\hline 18 & 2164.2 & 186 & $\begin{array}{llll}18 & 3 & 2 & 1\end{array}$ & \\
\hline & $\begin{array}{llll}7 & 15 & 10 & 8\end{array}$ & 20191 & $2212 \quad 3$ & \\
\hline & 1132179 & 3738 & $\begin{array}{llll}37 & 18 & 5 & 9\end{array}$ & \\
\hline 14 & $\begin{array}{llll}11 & 10 & 13 & 8\end{array}$ & 2319 & $318 \cdot 3$ & \\
\hline & $3376,48,28$ & 90 & 715441373 & \\
\hline
\end{tabular}

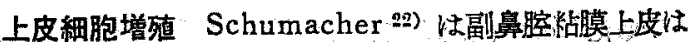
多列線毛上皮であるが鼻膑の上皮より低い，しかし部分:

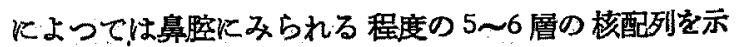
し，又2〜3 層の核配列のところるあると云つているが， 


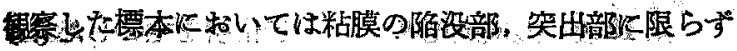

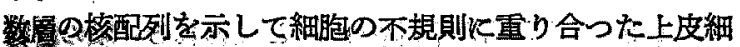
胞增殖暗が 所ににみられた，5〜6 層以上の 堌殖が明に

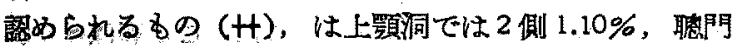
部では 1 側 $0.56 \%$ ；節骨洞では 2 側 $1.08 \%$ であつた(第 9.表):名入る上皮細胞增殖について片岡は 13 洞（全 43 例)に持いて観察され，3例は最も顕著であったと述べ， 姜はや宫度なるすのは5〜6層からなり，比較的広範

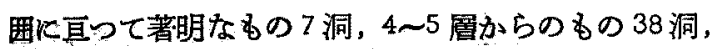
2 3 層のもの67洞（全197 洞）と記しているのに比心 ると小罗に和ける私の観察では遥が少い上うに見受け

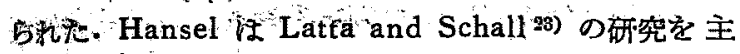
注して，副鼻腔の上皮は外界に甜ける変化に対して強い 適応为を有し例えばアレルギー，急性炎症等の異常条件 に奶し下部組織を保護するよ5に反応しその緻密さ厚さ 感堌加し，基底緗胞は者明に増加すると云い，結局重層 円柱上皮の状態沈まてるなるといつているが以上の如く 成人活どかかる増殖は多くないようである。

㳅状細胞，正常粘膜です上皮細胞間に混じて存在する と云われるが，細胞体は杯状に膨满し透明で核は比較的 下方に在在し粘膜宿没部で多くみられた・へマトキシリ

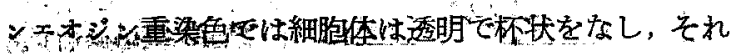
に線毛を有する上皮細胞よりの移行形々考えられるもの も相当に観察された. 第9 表の如く H (中等度)，卅 (高 度)に認められるるの合計して上㖽洞では 4 側 $2.2 \%$ ， 上顎洞缌門部 2 側 $1.12 \%$ ，節骨洞 26 側 $14.05 \%$ で管骨洞 粘膜では他粘膜より多くみとめられた。

Latta and Schall は上皮の基底細胞はその刺战の差 によって線毛細胞むるいは杯細胞にもなる能力を有して いると述べてょう，Hansel ${ }^{15)}$ は強く長期に亘る刺㦸に よつて杯細胞は増加すると云つているが，西端は炎症の 案外軽度の 例にかえつて 本細胞が著明であるといい， Nuhsmann, 片岡も浮腫型のすのに概して多いと述べて

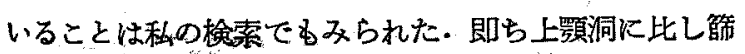
骨洞に多く文浮腫型のものに多くみとめられた．白川 2i) は Schmidtmann, Hajek, Messerklinger 等の研 究をるとにして杯状細胞は病的状態に执いては線毛上皮 から移行するその証拠として粘膜内には杯状細胞と別に 線毛は有するがムチンを含有する杯細胞えの移行型と思 われるすのが存在するからであると云つており，上皮細 胞がムチン化しているものは大部分がアレルギ一型, 混 合型て化膿型では極めて少数であるとしている・私の検 索で浮䭪型のものに多いこと，又著明な好酸球漫潤，
浮䭪及び全上皮層に亘る杯状細胞とが同時にみられた例 が存在したこと等は炎症刺战あるいは反応様式の特異性 を想像させた。

上皮化生 円柱形の上皮細胞方唰平な文は立方形の状 態を呈するのは粘膜の突出部にみられたが，その例は僅 少でこく小籍囲にみられたにすぎない.その状態る扁平 化えの移行型と考えられる不完全なるのであつた. 以上 の状態のみとめられたものは第 9 表に示す如くで節骨洞 粘膜ではみとめられなかつた。

Oppikofer ")は上皮化生の原因について慢性炎定， 機械的，化学的，温熱的刺战の影響をのへててをり 200 例

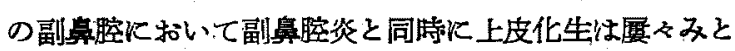
められたと述へている。後藤 31) は扁平上皮は認めない といつているが，西端，横出は30\%にみとめ吉野も完 全に扁平化したものは1 例るなかつたが，24 側 $23.8 \%$ にみられたと述へていることと比へると前述の如く小罗 では成人上りその状熊ははるかに少い上5である・筒井 9y）小罗に拉いては上皮化生の如き高度変化はみない と述べている。

上皮变化程度 前述した变化のほかに杯状細胞の数個 集合して上皮内腺を形成するすの，䅫毛の膠着し合った もの，又脱落したもの，上皮細胞配列の乱れて不規則に なっているすの等が観察された. 以上述べた各变化を綜 合して上皮の変化程度を高度 $(\mathrm{H})$ ，中等度 $(\mathrm{H})$, 軽度 (十)，殆んど正常だと思われるすの（ー〜士）に分行る

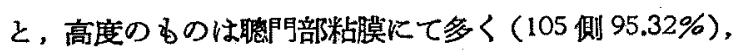
節骨洞では少くなつている (48 側 25.32\%). 上䫇洞では 62 側 35.03\% であつた. 年令別に高度変化のものを観察 してる有意の差は嫼められない，粘膜病型との関係は第 10 表の如くで中等度以上の 变化群は上䫇洞にて, 浮腫 型では9 側 $37.5 \%$, 浸潤型では 23 側 $76.66 \%$, 線維型で は 19 側 $86.36 \%$ ，穊骨洞にて浮腪型では 24 側 $64.86 \%$ ，

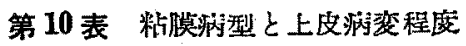

\begin{tabular}{|c|c|c|c|c|c|c|c|c|}
\hline 澫型 & 0 & 01 & 1 & $I F$ & $F$ & FO & $N$ & 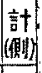 \\
\hline $\bar{z}$ & 15 & 13 & 7 & 14 & 3 & 9 & 1 & 62 \\
\hline & $g$ & $\begin{array}{r}11 \\
6\end{array}$ & $\begin{array}{c}3 \\
20\end{array}$ & $\begin{array}{l}21 \\
23\end{array}$ & 8 & $\begin{array}{l}4 \\
2\end{array}$ & 1 & $\mid \begin{array}{l}57 \\
62\end{array}$ \\
\hline $\mathrm{st}$ & 24 & 30 & 30 & 58 & 22 & 15 & 2 & 181 \\
\hline $\bar{I}$ & 13 & 7 & 3 & 3 & 6 & 3 & 20 & 55 \\
\hline 年 $\mathrm{H}$ & $\begin{array}{c}16 \\
8\end{array}$ & $\begin{array}{r}8 \\
5\end{array}$ & $\begin{array}{l}7 \\
7\end{array}$ & $\begin{array}{l}4 \\
7\end{array}$ & $\begin{array}{l}20 \\
10\end{array}$ & $\begin{array}{l}2 \\
7\end{array}$ & $\begin{array}{r}25 \\
9\end{array}$ & $\begin{array}{l}82 \\
48\end{array}$ \\
\hline $\mathrm{z}^{\prime}$ & $\frac{0}{37}$ & 20 & 12 & 14 & 36 & 12 & 54 & 185 \\
\hline
\end{tabular}


浸潤型で汭 9 側 $75 \%$; 線維型で 30 側 $83.33 \%$ であつ て，一般に漫潤型，線維型で变化度加高いさ5であっ た.このことは次に述べる上顎洞注入造影郕の排㵽状態 からも推爵し得た。

附）上顎洞注入造影成の排洋状態

洞内注入溶液の排泄法洞粘膜の線毛運動炕よって直接 行われる40) と云われるが，20\%モルョドール注入によ つてその排泄状態を観察したが，その判定規準として倉 田 ${ }^{47)}$ の 4 排泄型の分類にしたがらた・即ら

1）完全排泄型，注入造影剂加4 日後のレ線撮影飞上 り完全排淋をみたもの。

2) 不全排浛型，注入造影刘の 犬部分壮 4 日後炕排泄 されているが，一部分はなを洞内諗められるする。

3）遅延排泄型，注入造影刘の 犬部分汢4 日後炕なお 洞内に認められるもの.

4) 不定排泄型，注入影像の所見高度にす抬らず，4 日後に完全排泄されたもの奴ひ注入㭙あるいは4 日後の レ線像より分散せる造影浏影像を認めたすの。

これによると第 11 表示寸如く高度の排澌障害ど考兄ら れる 遅延型及び不定型は浸潤型，線維型比多くみられ る。即上皮変化度の高い浸潤型，線維型飞著明と云うこ とになり，術前においてある程度まで主皮变化の程度は 推測されらるよう思方れる。

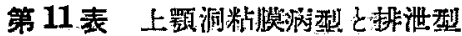

\begin{tabular}{|c|c|c|c|c|c|}
\hline 建便垃 & 完全 & 不全 & 䢭婿 & 不定 & 話 \\
\hline 0 & 1 & 6 & 2 & $Z$ & 11 \\
\hline 01 & 2 & 3 & 6 & 3 & 14 \\
\hline 7 & & & 6 & 4 & 10 \\
\hline$I F$ & 1 & 1 & 9 & 11 & 22 \\
\hline$F$ & 1 & 3 & 2 & 4 & 10 \\
\hline FO & & & 2 & & 2 \\
\hline 計 & 5 & 13 & 27 & 24 & 699 \\
\hline
\end{tabular}

＝）被覆上皮下基宣膜の变化

上皮值下にある菲薄な蟍密な膜で，鋌銀染色によって 明瞭にみとめられるが，銀線維網が粗箖化し明瞙にはみ とめられないるのるあった：武藤 43)は鼻粘膜呼吸部の 多列線毛上皮下の基底膜は新産胃に䗆いてすでにみとめ られるが，生後一年位で軽度ながらその直下に一種の生 理的硝子化が膜状火抏こりそれ年令と共汇次第に著明 化するといい，これは気道と云う臓器にをける Roux の隐味での機能的適応想像を解すべきだろうと云ってい ろ.今まで観察されてきた基宣膜の状態はこの二次的硝

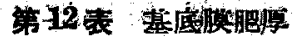

\begin{tabular}{|c|c|c|}
\hline 輙 & T & \\
\hline $6+1$ & 10 & 10 \\
\hline 8.9 & 203 & 23 \\
\hline 70 & 345 & 39 \\
\hline $12 \%$ & $\begin{array}{lll}56 & 8 & 2\end{array}$ & 66 \\
\hline $14 \sim 75$ & 393 & 142 \\
\hline 計 & $195 \quad 19 \quad 2$ & 78 \\
\hline 627 & 63 & 9 \\
\hline $8 \sim 9$ & $\begin{array}{llll}14 & 7 & 3 & 1\end{array}$ & 25 \\
\hline $10-11$ & $246.2 \%$ & 33 \\
\hline $12 \pi / 5$ & $\begin{array}{llll}36 & 27 & 2\end{array}$ & 66 \\
\hline $14-15$ & 309.73 & 43 \\
\hline 計 & 1105286 & $7 \pi$ \\
\hline $6 \sim 7$ & 64 & 10 \\
\hline $8 \div 9$ & 6143 & 23 \\
\hline $0 \sim 11$ & 9226 & 37 \\
\hline , & $2039 \quad 5 \quad 2$ & 66 \\
\hline $14 \%$ & 192071 & 41 \\
\hline ठै। & 6099153 & \\
\hline
\end{tabular}

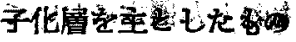

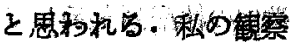

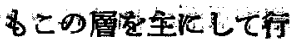
つた・この層は秝

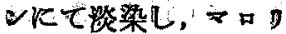
一染色て青色，甲ンギ ーッシ染色で淡紅色厄

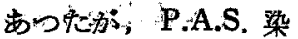
色无紫褐色起呈し肥厚

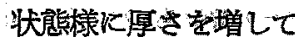
い当例不られた。

肥厚一上皮細㴔下全 長にわたって明膫に肥

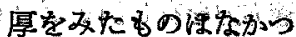
たがこれた近い状態 高度 (卅)としてみ ると第 12 表の姐くて，

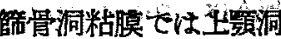

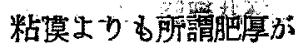
目立つようて昰る。 等度 $(H)$ 头上肥厚(附 因6) 々 粘脱病型々の 関係について みるて第 13 表の如くでり一般に肥厚の

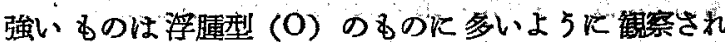
た.

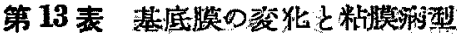
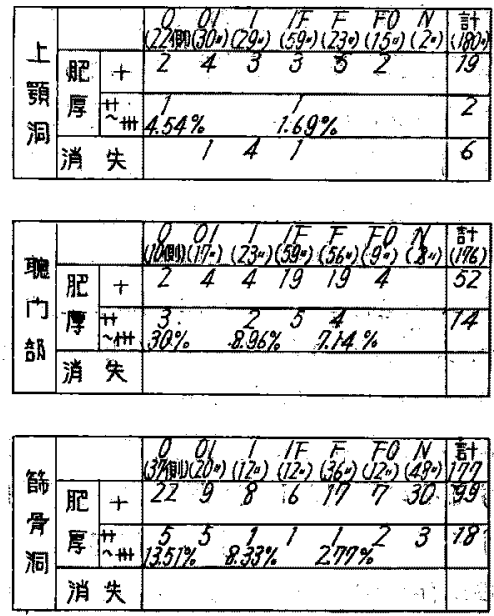

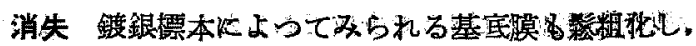

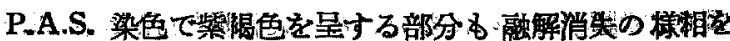


呈している個所が上䫑洞粘腽でぬられた・竞の程度は強

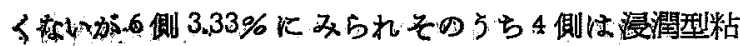

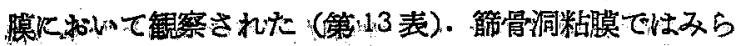
轨な的ら机.

Mannasse 9) 恃個々の場合によつて基底膜は異つた状 熊逊星し，殆んどみとめられない場合る又無細胞の硝子 様でォジン赤の層として上皮下にみられる場合もある と述へ，後藤恃正常粘荧 13 例火打いて 2 例炏のみ明かに 坊与机飞い6，Schambaugh 24) は上気道粘膜 440 例 について喘息患者つ $65 \%$ 以上では肥厚があったと云い， 好酸球浸潤と関係があるらと推察している.前述の武藤 48) の記述と考光合せ，節骨洞粘膜に更に浮腫型粘脱に その肥厚が多くみられることは，上皮杯細胞の増加とも 関連があるようでくり返される刺战によるのみでなく アレルギー性変化に関係があるらしいと云われているよ 5に，炎症に乱けるある一面の反応が強く現れた結果だ 々推察される．基底膜の消失に関連して武藤 48) は炎应 性細胞浸潤が粘膜上管に著しい場合はそれ儿相度して基 底朕の矧粗化と其にその直下の硝子化層が著しい遊走細 胞の浸潤をうけて多孔性となり，部分的に殆んど融解消 失の状態を示すことは稀でないと述べている.

\section{ホ）腺組織の状態}

附）副畀胵内䁸汁について

副睢腔粘膜の腺は鼻腔粘膜のそれと同じであるがその 発育は弱いと云われている。西端 ${ }^{38)}$ は相当多いもので

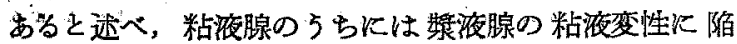
ったるのが仲々多いと云つている. 叉 Eggstōn and Wolff ${ }^{13)}$ 性混合腺の存在を記載しているが，私の検索

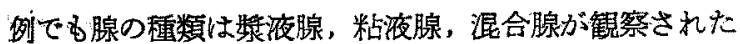
'が', 本来上りの混合腺なのか獎液腺から粘液腺之の移行 型なのか判然と区別はできないようである・各粘膜につ いて腺の榆出程度をみると第 14 表つ如くで，卅（高度）

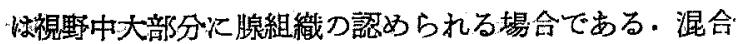

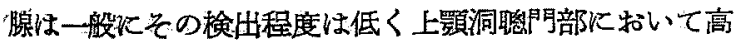
度 (H) 1 側，中等度 (H) 1 側が認められたにすざな い. 腺は㯖門部粘膜に最も多く検出され，影液腺が多く 次いで粘液腺，混合腺の順となつているが，篩骨洞粘脱 で悎液腺の高度に検出されるものより粘液腺の高度に みられるものが多いようである.腺の多宾と年令との関 係沉ついてる特別の関係はなかつた・粘膜病型との関俰 Kついては第!5 武炕示す如くで，徆液腺の中等度 $(H)$ 出留绘出度のものは上顎洞では浮腫を主とするすの $(\mathrm{O}, \mathrm{OI})$ K $18.51 \%$ (54 側中 10 側)，線維化を主とする

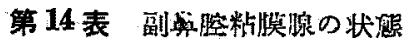

\begin{tabular}{|c|c|c|c|c|c|c|}
\hline \multirow{2}{*}{ 週 } & \multicolumn{2}{|c|}{ 上顎洞 (192側) } & \multicolumn{2}{|c|}{ 玨门部 (190側) } & \multicolumn{2}{|l|}{ 籍骨洞(180㪘) } \\
\hline & $-+H+H$ & 計 & $-+H \mathrm{HI}$ & 計 & $-+H \mathrm{H}$ & 計 \\
\hline & 172 & 10 & 261 & 9 & $\begin{array}{lll}16 & 3\end{array}$ & 10 \\
\hline 策 $|8+9|$ & $17 \quad 5 \quad 3$ & 25 & 1897 & 25 & $\begin{array}{llll}4 & 15 & 3 & 1\end{array}$ & 23 \\
\hline 浓 & $\begin{array}{llll}5 & 26 & 10 & 1\end{array}$ & 42 & $12015 \quad 5$ & 41 & $1027 \cdot 3$ & 40 \\
\hline & 848113 & 70 & 4.332014 & 71 & $2438 \quad 4 \quad 1$ & 67 \\
\hline 成 $\mid 4 / 5$ & $\begin{array}{llll}3 & 31 & 9 & 2\end{array}$ & 45 & 222146 & 44 & $1325 \quad 2$ & 40 \\
\hline 計 & 771293799 & 192 & 88564,33 & 190 & $5271715 \mathrm{zm}$ & 180 \\
\hline $6 \cdot 7$ & 91 & 10 & 432 & 9 & 627 & 10 \\
\hline 年 $^{8-9}$ & 223 & 25 & $\begin{array}{llll}7 & 10 & 6 & 2\end{array}$ & 25 & 1110101 & 23 \\
\hline 60,1 & 3561 & 42 & $\begin{array}{llll}16 & 12 & 9 & 4\end{array}$ & 41 & $\begin{array}{llll}33 & 2 & 3 & 2\end{array}$ & 40 \\
\hline 洨 $\mid 1213$ & 5713 & 70 & $23 \quad 2514 \quad 9$ & 77 & $4714 \quad 4 \quad 2$ & 67 \\
\hline 腺 $44 \times 5$ & 3510 & 45 & $\begin{array}{llll}14 & 21 & 6 & 3\end{array}$ & 44 & 29773 & 40 \\
\hline 計 & 75833 & $\mid 92$ & 64713768 & 790 & $726 \quad 35 \quad 10 \quad 9$ & 780 \\
\hline $6-7$ & 10 & 10 & & 9 & 91 & 70 \\
\hline 混 8.9 & 25 & 25 & 27,4 & 25 & 194 & 23 \\
\hline ธิ $\mid(2,1)$ & & 42 & 33.8 & 41 & 391 & 40 \\
\hline 䛲 $\mid 1213$ & 673 & 70 & 5416 & 77 & 607 & 67 \\
\hline $44 \times 5$ & 432 & 45 & 33.107 & 44 & 373 & 40 \\
\hline 詰 & 1875 & 792 & 150381 & & 16416 & 780 \\
\hline
\end{tabular}

第 15 表 粘 膜濯 型 と腺

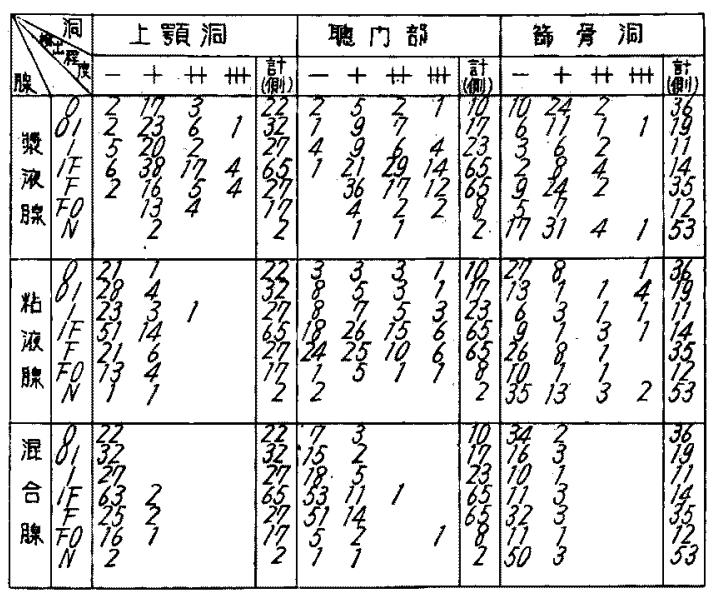

屯の (F, IF) K $33.69 \%$ (92 側中 30 側)，上頡洞聰阴 部では前者に $37.03 \%$ (27 側中 10 側)，後者に $55.28 \%$ (130 側中 72 側)，笠骨洞では前者に $7.28 \%$ (55 側中 4 側)，後者化 $12.24 \%$ (49 侧中 6 側) であって各粘膜を通 じて浮腫を主変化とするるのより，線維化を主とするる のに漿液腺の検出度は高い上うに思われる。節骨洞粘莫 では粘液腺の中等度 (H) 以上検出度つるうは，浮腫を 主变化とするすのに 29.09\%(55 側㠳6 側)，線維化を主 とするものに 10.2\% (49 側中 5 側) で浮腫を主変化とす るものにより多くみられた・このように篩骨洞で粘液腺 
が浮腫型粘膜に多く，漿液腺よりもその検出度が高いと

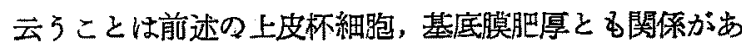
るように思かれ，上皮細胞の杯状細胞えの変化と同しよ うに徆液腺の粘液腺化と云うことが浮腫型粘膜，節骨洞 粘膜に括いてより多く行われるように推察された。 Weille ${ }^{17)}$ はアレルギー性変化のある場合には普通へマ トキションェオジン染色で萛白色を呈する粘液腺が，基 底膜近くでかすかにビンク調をおびる・この腺は本来は やはり粘液腺よりもむしろ俩液腺であつて，嶈液細胞か ら粘液細胞えの化生であることを暗示すると述べ漿液腺 の粘液化を強調している.

名越 25) は線維增殖の結果として腺が 圧迫菱縮におち いった所見はなかつたと云つているが，私の観察例では 上顎洞で 軽度菱縮のもの $5.49 \%$ (182 側中 10 側)，聘門 部で中等度萎縮 0.53\% (190 側中 1 側)，軽度萎縮 17.37 \% (190 側中 33 側)，節骨洞で軽度菜縮 3.97\% (151 側 中6 側) がみられた即聰門部では腺の発達も他部に比し て強いが，萎䌅消失の傾向もより多くみとめられた。

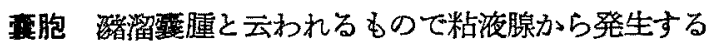
と云われる. 西端, 横出 ${ }^{33)}$ は高度, 中等度, 軽度のる の合せて 10例 16\%を観察しているが，私の観察では次

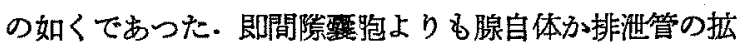
大によって形成されれをと思われるむのが多いようであつ た・拡張した排泄管壁の破綻によつて内容が周囲の組織 え流出している状態も2，3にみられた(附図 12).

比較的数むあり要胞も相当大きい場合

上頡洞で 6 側 $3.26 \%$

聰門部 2 側 $1.04 \%$

節骨洞 2 側 $1.32 \%$

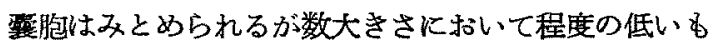
の
上顎洞で 42 側 $22.82 \%$
聯門部 12 側 $6.28 \%$
節骨洞 14 側 $9.27 \%$

で上顎洞粘膜に比較的多いようである、霆壁は単層むる いは電層する比輘的だけの低い細胞から成るが，礝胞の 大きなものの壁は扁平化している・文その外壁はニォジ ン赤の無構造碚子様物質で帯状に囲續されている（附 区11）のああり，内容はへマトキシリンに淡紫色で,

P.A.S. 染色で梁青色に染る粘液㴍物質が主で，円形細 盷が2〜3ケみられるものむあった. 以上の如く成人の 場合と大差ないようである. 页年令的にも差はみられな からた。
附）副鼻腔内膿汁について

腺の種類々上題洞内容との関係についてみを結果注? 腺の種類と内容の性状とは特別な関連はみられなか心质 が, 粘䐺病型の浮嗹型，浸潤型，線維型のおのについて 副鼻䐋内膿汁をみると第 16 表の如くで，浮腫型，線維 型つもので過半数以上が洞内容は陰性であり，浸潤型の ものでに洞内容陰性のもの少く，過半数以上飞秥膿性， 純滕性つ内容物を検出した：この上うに洞内容物の性状 は腺よりの分䎵物以上に感染炎症の程度に左右されてい るようである。

第 16 表 粘膜鸿型と润內容

\begin{tabular}{|c|c|c|c|c|}
\hline 洞 & \multicolumn{2}{|l|}{ 上嘪洞 } & \multicolumn{2}{|l|}{ 篻洞 } \\
\hline BDit wy & $0 / F$ & 計 & $0.1 F$ & 計 \\
\hline$(-)$ & $\begin{array}{lll}17 & 3 & 12\end{array}$ & 32 & $\begin{array}{lll}19 & 4 & 22\end{array}$ & 4.5 \\
\hline 粘液性 & 1 & 1 & 2 & 2 \\
\hline 炶殿性 & 376 & 16 & $\left|\begin{array}{lll}14 & 6 & 12\end{array}\right|$ & 32 \\
\hline 礼滕性 & 4161 & 27 & 32 & 5 \\
\hline 計 & 242620 & (6) & 387 & $\mid \begin{array}{l}84 \\
(94)\end{array}$ \\
\hline
\end{tabular}

へ）血管の变化

血管自体の变化がすべての細胞に影響するとすればを： の変化は重要な意㸬をるっ．小見でも比較的著明にみら れるものもある. Hansel ${ }^{15)}$ は慢性炎に括ける血管の变 化は著明で数の増加があり，概して大なる血管ではその 壁が厚くなり線維状になる傾向がみられ，高度か慢性炎 では壁つ肥厚が著明で完全に閉寒するすのもあるが，： 過性つ急性フレルギーでは腺や血管の永久的变化恃起ら ないと云つている. Eggston and Wolff ${ }^{13)}$ む血管の 变化は副鼻腔粘膜に慢性炎症が存したことの最す著しい 像だとし，Periphlebitis, Perilymphangitis k注目 しこれを浮盾つ原因とし，これら病变のために組織の酸 化が妨げられ，栄養が害され線維型つところではこれが るとで上皮やその他粘暁組織つ萎縮をきたすと述べてい る。

血行停止 血管は拡張し血管内の赤血球は互いに密着 し翏着しているもの，更に個々の赤血球を区別し得ない 状熊になったるのるみられた、第17.表に示すように上 顎洞粘膜に 括いてその像は他部战膜より強いようであ

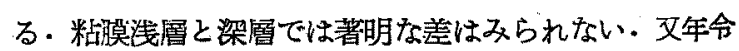
的にも一定つ関係はないようである・粘膜病型別にみる と上顎洞粘膜では第 18 表つ如くで，上顎洞.(195 側)で その程蔗中等度以上 $(H, H) の b の は$ 
第 17 表 血管の変化

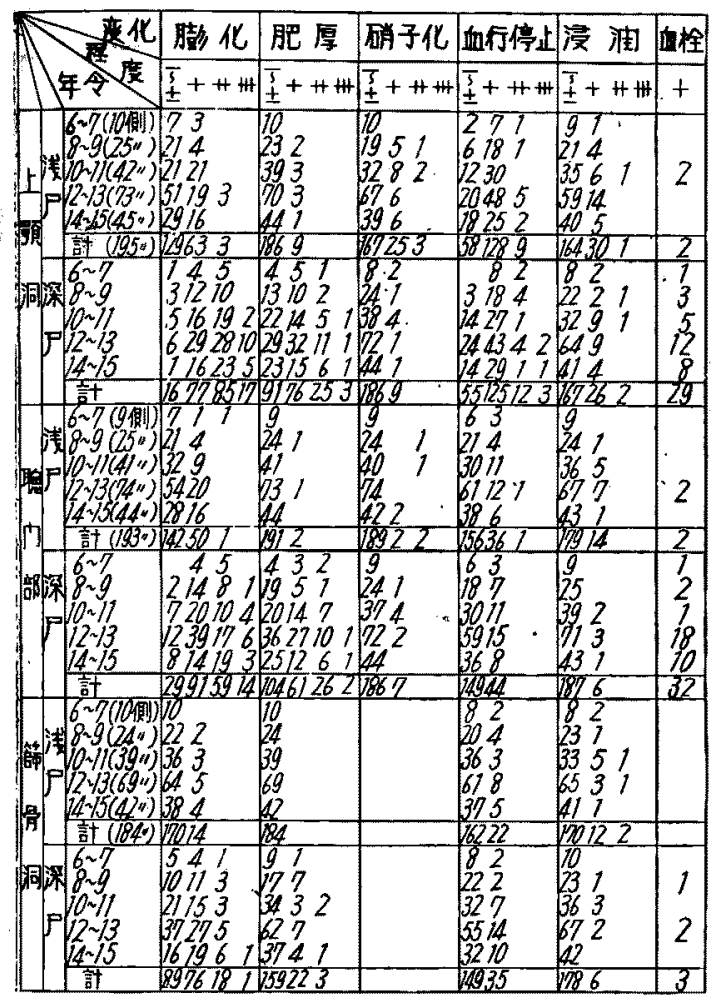

第 18 表 粘膜㵐型 $と$ 血管变化（上顎洞 195 側）

\begin{tabular}{|c|c|c|c|c|c|c|}
\hline \multirow{2}{*}{ 化 } & 脰少化 & 肥 厚 & 硝子化 & 血行停止 & 浸 油 & 血栓 \\
\hline & $\bar{I}+++H$ & $\bar{I}+++H$ & $\bar{t}+H+n$ & $\bar{I}++n+m$ & $\overline{\underline{1}}++H$ & $1-+$ \\
\hline & 7 & 1 & & 172 & 31 & \\
\hline (244919). & 8 & 1 & 2 & 221 & 7 & 1 \\
\hline (J) & 13 & 1 & 91 & 221 & 5 & 1 \\
\hline IF & 253 & 4 & 132 & 414 & 101 & \\
\hline$\frac{\left.6 b^{16}\right)}{F}$ & 7 & 2 & 1 & 141 & 3 & \\
\hline FO & 3 & & & 11 & 1 & \\
\hline$\left(\begin{array}{ll}(16) \\
N\end{array}\right.$ & & & & 1 & 1 & \\
\hline$\frac{12^{n}}{0}$ & 755 & 71 & 7 & 174 & $T$ & 5 \\
\hline 01 & 13142 & 124 & 2 & 2232 & 71 & 5 \\
\hline 1 & 11132 & 96 & 2 & 197 & 61 & 3 \\
\hline$/ F$ & 153617 & 3191 & 4 & 414 & 8 & 8 \\
\hline$F$ & 13121 & 1131 & & 131 & 3 & 5 \\
\hline FO & 951 & 521 & & 11 & 1 & 2 \\
\hline$N$ & 1 & 1 & & 2 & & 1 \\
\hline
\end{tabular}

浅層 浮腫を主とするるの(0,10) で3側 $5.45 \%$
線維化を主とするもの (F,IF) で 5 側 $5.43 \%$

潹層 浮腫を主とするるので9 側 $16.36 \%$

線䊒化を主とするるので 5 側 $5.43 \%$

となり粘膜梁層の比較的大きな血管に括いて線維型を主 とするものより，浮腫型を主とするものに高庭つようで ある・これは资症の比較的初期像つ循環障害に上る状態 であろう。

血栓 赤血球が雑然と凝集し血管内壁付附着している むの (附図 9), 更に器質化を示して 新生血管の 進入し ているものもみられた。 その例は少いが第 17 表の如く 粘膜浅層より梁層部に多い上5である・節骨洞粘膜では 上顎洞粘膜よりはるが少い粘膜の浮腫型，線維型にお

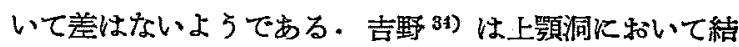
織性の栓塞や赤色，白色血桎を観察しこれらは血管周囲 炎から内膜炎を起し更に血流緩徐となり生ずると説明し ている。

血管壁及周围細胞漫潤 血管周囲及び血管壁に円形細 胞つ浸潤が明かにみられる例があつた(附図 7)。しかし その例は少く(第 17 表) 浸潤型の比較的に多い上䫑洞粘 膜により多く観察された。上顎洞粘膜では浅層, 梁層 注ぼ同程底にみられた．前述の如くこれらについては Eggston and Wolff 4 Periphlebitis, Perilympbangitis として觀察している.

血管壁硝子化 粘莫浅層の小血管壁がエォジンに淡染 を示し無構造に 肥厚しているのがみられた＼cjkstart第 17 表の 如くで篲骨洞粘膜ではみられなかつた，上䫇洞粘膜浅譄 で多少ともみとめられたものは 28 側 $14.35 \%$ ，上顎洞聯 門部では 4 側 $2.08 \%$ で，上顎洞粘膜浅層の血管壁硝子 化の状態を粘臊病型別にみると第 18 表つ如くで浸潤型 で 10 側 33.33\%，浸潤十線維型（IF）で 15 側 $22.72 \%$ ， 浮腫十浸潤型 (OI) で 2 側 $6.45 \%$ ，線維型で 1 側 $3.84 \%$ 即ち細胞浸潤を主とした粘膜病型つるのに明膫にるとめ られた・吉野 34) る成人上頡洞粘膜で細胞浸潤著明な上 皮下部では血管は多く肥厚して淤り，特に硝子様变性が 目立つたと述べている・

血管壁膨化 白川 ${ }^{37) ~}$ は浮腫刀存する所では㕍々血管 恃充血し一部には血柽を形成し又一部には血管壁が粗影 となり膨化し，その間に P.A.S. 陽性物質が存して明か に線維素様変性と思われるすのがあると述へ，仁保等 ${ }^{49}$ すアレルギー性変化つ一つであるフイブทノイド肥厚と 考党られる状態があると云つているが，筒井侨は血 管壁つフイプリノイド变性は全くみられなからたと述べ ている・私つ㭘索でも血管壁が粗獎となって膨化し（附 
図 8)，P.A.S. 染色で紫褐色を呈するようなものが 比較

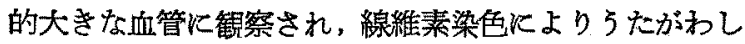
きるのるみられたが明か、線維素様变性と断定はでさな かつた・なをかかる膨化の高度なために血管腔が閉兴さ れる上5ないのはごくわずかしかみられなかつた・膨化 の程度について曲 (高度)，H (中等度)，十（軽度）に 分讨てみると第 17 表の如くで，一般に各粘膜とも梁層

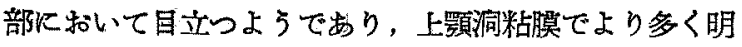
らかにみられた。年令的に差はないよ5であつた・粘膜 病型別にみると第 18 蒜の如くで上䫈洞粘膜深層に打い て中等度以上のむのは，浮庫を主な変化とするもの( $\mathrm{O}$, OI) で 21 側 $38.18 \%$ ，線䊒化を主とするもの (F, IF) で 60側 $65.21 \%$ となり線維性病変のあるものに多くみ

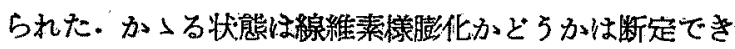
なかつたが，既にでき上つた線維が血管からの出反応

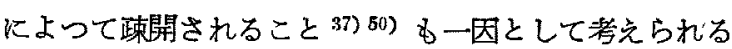
ように思われる。

血管壁肥厚 吉野は㷋症が反復され永続すると血管壁 は著明炕肥厚し完全な血行停止さ兄生ずると云らが，私 の検索です血管壁に結合織が密に堌殖して肥厚をきた し，高度の場合には管胵は狭少となり（附図 10)完全汇 閉塞している状態が屡々観察された。第 17 表に示す如 く一般に粘膜梁層部力血管に多くみられ，上顎洞粘膜と 上顎洞㙏門部粘膜では注よ゙同程度，節骨洞粘膜では少な

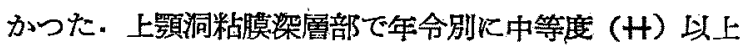
肥厚の状態をみると 6才〜9才 3 側 0.85\%，10 才〜11才 6側 $4.62 \% ， 12$ 才〜 13 才 13 側 $17.33 \% ， 14$ 才〜 15 才 7 側 $15.66 \%$ で年長者では若年者より肥厚のあるむのが多い よ5である. 更に粘膜病型別にみると第 18 表の如く中 等底 (H) 以上のものが浮腫を主とするものに 5 側 9.09 \%，線維化を主とするものに 14 側 $15.21 \%$ で後者に括 いて血管壁肥厚は目立つようであつた・大沢等 膜基底部の動脈系の変化として血管腔狭少，中膜の弾力

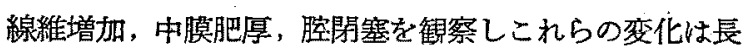
い間の機能障害の積み重なつた像で。この部分つ動脈系 に機能的に著しい荷重のあつたことが理解されると述べ ている・結局かつる高度な血管の変化が一因となつて粘 脱の不可逆性変化が憙起されてくると思われる。

血管变化程度 以上の如き循環障害及び血管壁の变化 を綜合して 観察し，その変化程度を高度 (†), 中等度 (H)，軽度及び正常に近いもの（+－）に分類すると 第19表の如くで一般に上顎洞では血管变化程度は高い が，節骨洞では遥か低いるのであつた。年令的にこれ
第 19 表 血管变化の程度

\begin{tabular}{|c|c|c|c|c|c|}
\hline 每 & 程度 & $-\sim \dot{+}$ & & HH & 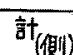 \\
\hline & $6 \sim 7$ & 3 & 6 & $T$ & 10 \\
\hline 上 & $8 \sim 9$ & 10 & 11 & 4 & 25 \\
\hline 額 & $10 \sim 11$ & 16 & 13 & 13 & 42 \\
\hline 洞 & $12 \sim 13$ & 29 & 28 & 16 & 73 \\
\hline & $14 \sim 15$ & 14 & 19 & 12 & 45 \\
\hline & 訫 & 72 & 776 & & 795 \\
\hline & $6 \sim 7$ & 2 & 6 & & 9 \\
\hline 聰 & $8 \sim 9$ & 15 & 5 & 5 & 25 \\
\hline & $10 \sim 11$ & 13 & 19 & $g$ & 41 \\
\hline J & $12 \sim 13$ & 30 & 26 & 18 & 74 \\
\hline 部 & $14-75$ & $g$ & 18 & 17 & 44 \\
\hline & 計 & 69 & $74=$ & 50 & 193 \\
\hline & $6 \sim 7$ & 9 & $\frac{0.6 .24}{7}$ & & 70 \\
\hline 篩 & $8 \sim 9$ & 20 & 4 & & 24 \\
\hline & $10 \sim 11$ & 36 & 2 & 1 & 39 \\
\hline & $12 \sim 13$ & 65. & 4 & & 69 \\
\hline 洞 & $14 \sim 15$ & 39 & & 1 & 42 \\
\hline & 計 & 169 & 138 & & 184 \\
\hline
\end{tabular}

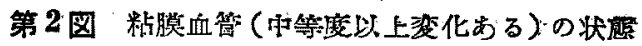

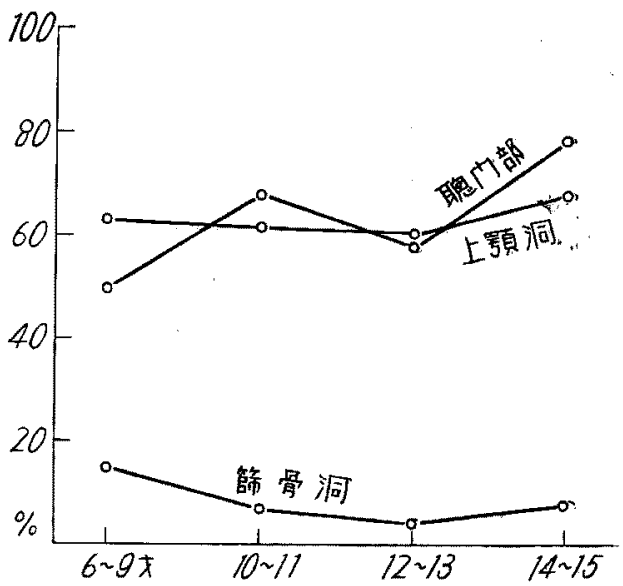

をみると第 2 図の如くで，聯門部粘膜に打いてて年令が長 するにつれて病变が強くなるようでありた $(\mathrm{P}<0.05)$. 更に粘䐉病型別に中等度以上变化度のものについてみる と第 3 四に示す如くで，上顎洞について浸潤型，線維型 となるにつれて浮腫型に淤けるよりあ変化が強くなり， しかし線維型ではや」变化程度は低下している。これは 
浸潤の旺盛な急性状態からの鎮静による血管变化の部分 的恢復ではなかららか. 第 3 図からみればこのことは第 骨洞ですみられるが炎症の強度でないために，その恢復 が非常に良好なためかあるいは最初から血管変化の少な からたことを想像させる。

第3 图 粘膜血管（中等度以上变化のもの） 子粘膜病型

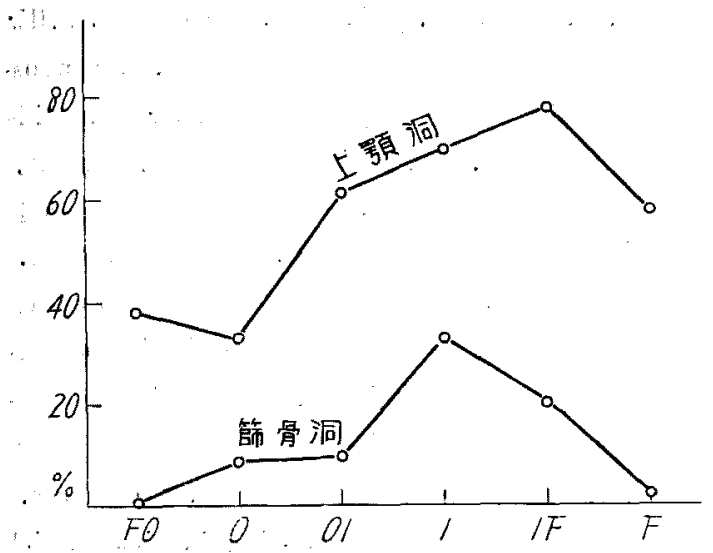

4. 綜括

副悬腔炎なる炎症も一つの動的な過程であつて，その 形態像の諸相の中下，副鼻腟炎に関与する種々な因子が 包含されていると云えよう・かかる形態像の諸相によつ て副鼻腔炎粘膜の病理学的分類が諸大家によってなされ てきたわけであるが，同一粘膜に和ける病像の多栐性の ために又各病型相亘の閜係がそれほど明確でないので资 䄞の所見を何れの型に当はめるか困難を感ずるわけであ る. 白川 27) は組織像発生の機序についてその原因とし て，基本的には細菌感染とアレルギー反応とに分けられ この 2 因子が種々の組合せ炕って作用したものと考光 らると云い，これらの影響する因子として自律神経機 能，内分汹機能，塩類代謝，ビタミン等があげられると 述へているが，私は吉村の云う雑多な組織像は炎症の Phase によると云うことを基礎として Mannasse の 分類化ならつてその分類を行つた. 即ち前述の粘膜固有 層に抬ける浮腫, 浸潤, 線維化の程度によつてその型を 表現した・浮連型 (O), (浮腫十浸潤) 型 OI, 浸潤型 (I)（浸潤十線維）型 IF，線維型 $(F)$ ，(浮朠十線維） 型 FO である.これらを成人の場合と比較すると小児 では浮膰を主とするるのが稍々多く，線焳化を主とする ものが幾分少い，浮腫病変の目立つことは炎症が比較的 初期の状態であろうと云うことと，小胃一般の特質とし

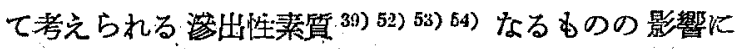
よってカタル性焱症が成人よりる強く現れる結果と考え

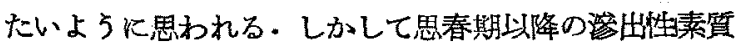
の淢少小小昆慢性副鼻腔炎自然治挜の一因々推察かされ る・しかし血管，上皮等に高度な变化を萑起したような 場合は粘膜病变は不可逆社となり時と共汇成人に和りる 慢性副鼻聜炎えと推移するもののよ 5 に考えられる・上 皮の得脱仙機㧴的操作によつて括こる場合が考えられ る.その他上皮には堌殖，杯細胞増加化生等がみられた が増殖，化生ば成人に郝けるはど明らか火は認められな いようである・上皮細胞つ粘液变性と思われる杯細胞の 增加と，基底膜の肥厚及び粘液腺の多い状態等は共に䦎 係があるようで，浮連型粘膜に多く又これらの状態が䈔 骨洞粘脱により多くみられたことは炎症初期の像として 一括せる浮腫型の中心炎症形式の一面が強調され修飾さ れた一つの型が含まれていることを推測させる・阿部

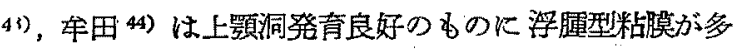
いとして局所体質因子の影響を強調したが，私の例では 前述の上了に発育良好のるのに線維型より浮腫型が明か に多いと云了結果にはならなからたが，発育不良と考光 られるるのには明かに楾維型つものが多い上らであつ た。

上皮層の病变程度は浸潤型，線維型に高いことは注入 造影剂排泄炕よる機能的な面からも認められた。このこ とは吉野 ${ }^{34)}$ も成人次いて同様に述べている・腺は漿 液腺，粘液腺，混合腺の三種がみられ，上顎洞惢門部に 腺の分布は多いが，篩骨洞に粘夜腺の目立つたことは固

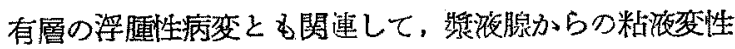
と云うことを想像させた・血管変化については小児です 比較的明がみとめられふが，片岡32）の43例中5 例 に血管壁の顕著なる肥厚を諗めたと云つているのに比べ ると，私の場合第 17 表の如く高度慢性炎の結果と考兄 られる著明なる肥厚は遥かに少小上うで，小昌では成人 よりも病变の程度がなを軽いもののように推察せられ る・望月す小奣では病变は新しく可逆性であると述べて いる. 浮腫型のむのに血行停止像が多く，線維化が進み 年長者になるにつれて顕著な血管壁の肥厚がみられるよ うであつたが，要するに血管の変化の著明なすのは浸潤 型，(浸潤十線維）型に多く，浮腫型では変化は軽いよ ろである - 即ち炎症初期と思われる浮原型には永久的な 血管变化はまだ起らないよらである。

又節骨洞に招いてはその炎症刺㦸つ蒻いためか天野の 云う組織賦活反応が強い上うで浸潤型る少く，血管变化 


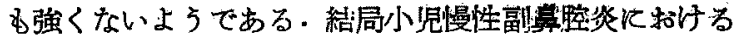
粘膜病変子成人刀それと本質的炕差は認められないが，

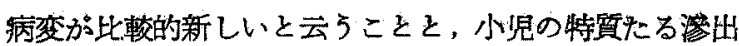

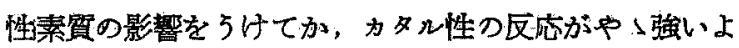

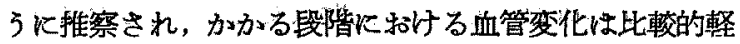

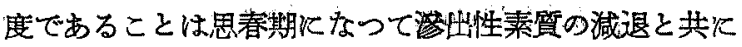
自然治整と云うことの有力な要素の上う火思われる。

\section{5. 結語}

6 才 15 才までカ慢性副鼻蚣炎根治手術例 100 例 200

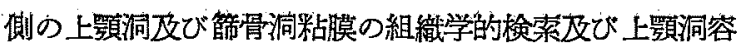
積，副鼻腔内澧汗，上顠洞注入造影剂の排泄状態につい て観察した.

1) 浮潤性变化は成人に比して一般に目立つようであ つた・これは炎症が比較的新しいことつ小罗の漻出性素 質が影響しているように思かれた。

2）細胞浸潤は浮潤と同様粘膜浅層に 著明であり，節 骨洞粘膜では浸潤程度は低い。浸潤細胞は淋巴球最も多 く次いで組織球，形質細胞，好酸球，好中球つ順であつ

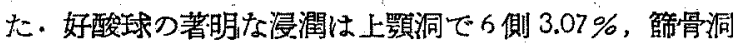
で2 側 $1.07 \%$ であつた。

3）結合織の堌殖は 成人に比してその程度は弱い，線 維芽細胞つ堌殖は穊骨洞粘膜で目立つようであつたが， これは资症刺战の弱いためこの細胞つ繁殖反応が際立つ ためであろう。

4) 副鼻腔炎粘膜を浮潤型，(浮潤十浸潤) 型, 浸潤型, （浸潤十線維）型，線維型，(浮潤十線維）型及び正常型 火分類した・上顎洞発育不良と思われるものは線維型が 多かつた。

5）上皮の変化は浸潤型，線䊒型となるにつれて強く なり，これは注入造影剂の排泄状態からも推察できた。 年令的には差はみられなからた。

6）基底膘厚は浮涯性変化の 強いものに多く又とめら れた。

7) 腺組織は獎液腺, 粘液腺, 混合腺で上影洞婘門部 に多く，一般には漿液腺が多いが節骨洞では粘液腺が優 勢であつた・上顎洞内膿汁は粘膜の腺種とは無関俰で粘 膜病型と閭保がみられた。

8）血管変化は浮潤性のものに軽度で浸潤型, 線維型 で高度であつたが，一般に成人よりる高度変化は少いよ うであつた。

9）小児に和ける副鼻腔粘膜病变は成人に括けるより 新しく，カタル性つ病像がや〉強いようであつた。

\section{文 一献}

1) Harke, E.A.T.: Grooks; j. \& Signy, A.G. Ar-

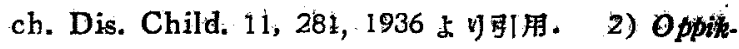
cfer, E.: Beitrage zür normalen und pathologisohen Anatomie der Nase und ihrer Nebenhơhlẹt. Arch. f. Laryng. 19, 28, 1909. 3) Dean, L.W.: Parnasal sinus disease in infants and young children. J. A. M. A. 85, 317, 1925, 4) Dean, L.W.: Nasal sinus disease in small children. Laryngoscope. 40, 371, $1930 . \quad 5)$ Carmack, J.W.: Sinusitis $i_{n}$ children. Ann. oto. Rhin. \& Laryng. 40, 515, 1931. 6) Spielberg, W.: Pathology of chronic sinusitis in children. Ann. oto. Rhin. \& Laryng. 43, 826, 1934. 7) Mensing, G.: Untersuchungen bei Kindern über den Einfluss des Schleimhautcharakters auf die Entwicklung der Nasennebenhöhlen, zug]eics ein Beitrag zur Frage des Werres der Diaphanoskopie. Arch. f. O.N. u K. h. $146 \mathrm{~B}, 1939.8$ 8) Hajek: 日耳耳算全畫, 第 2 卷, 第 1 册，167頁上り引用. 9） Maneasse, P.: Die pathologische Anatomie der Nebenhöhleneiterungen. Zschr. f. H.N. u O H. k. 4, 473, 1923. 10) Nohsmann, Th,: Die entzundlichen Erkrankungen der Kieferhöhle. Denker-Kahleis Handbueh d. H. N. o. Bd 2, 573, 1926. 11) Mullin, W.V. and Ball, R.P.: Studies of pathologic tissue removed from chronically infected nasal and accessory sinuses. Ann. oto. Rhin \& Laryng. 37, 182, 1928. Birrel, J.F.: Chronic maxillary sinusitis in children. Arch. Dis. in childh. 27, 1-9, 1952. 13) Eggston, A.A. and Wolff, D.: Pathology of the nose. Histopathology of the Ear, Nose and Throat. (Willams \& wilkins, Baltimore) 613, 1947. 14) Menkin, V.: 林秀男訳, 炎症の新しい裙念, 医学 書院, 1954. 15) Hansel, F.K.: Clinical allergy (C.V. Mosby, st. Louis) 341, 1953. 16)Coates, G. M., Ersner, M. S.: Occurrence of eosinophils in the mucus membrane of the maxillary sinus. Arch. oto. Laryng. 11, 158, 1930.17 ) Weille, F.L.: The pathology of allergic tissue as seen in the nose and accessory sinuses. Arch. otolaryng. 12, 785, 1930. 18) Kline, B.S.: Tissue changes in allergy. J. allergy. 19, 19, 1948. 19) Cutore: D. 
K. Handbuch d. H.N.O. Bd 1, 286 \& V召用. 20) Schall, R.A.: The histology and chronic inflammation of the nasal mucous membrane. Ann. oto. Rhin. Laryng. 42, 15, 1933. 21) Anderson, H.: The common cold. Arch. oto. 12, 133, 1930.22 ) Schumacher, S.: Histologie der Nase und ihper Nebenhöhlen. D.K. Handbuch d. H.N.O. Bd 1, 286, 1925. 23) Latta, J. and Schall, R.: The Histology of the Epithelium of the para nasal sinusesunder various conditions. Ann. oto. Rhin. \& Laryng. 43. 945, 1934. 24) Schambaugh: 日耳 全晋，第2管，册，200頁引用. 25）名越，三

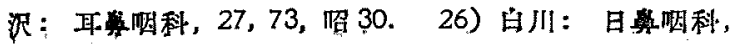

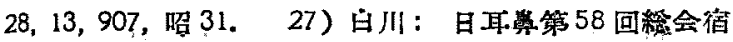

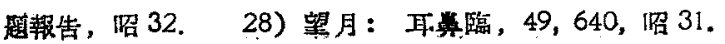

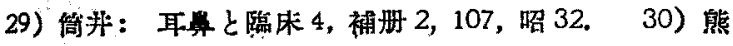

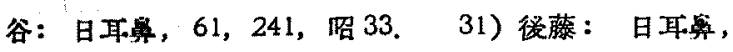

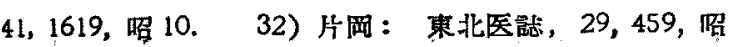
16. 33) 姜: 日耳鼻全書, 第 2 卷, 第 1 册引用.

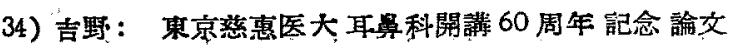

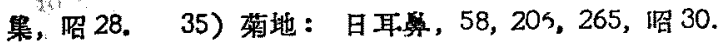

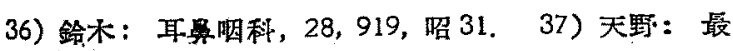
新医学，13，815，炤33.38）西端：日耳悬全書，第 2 第 1 册. 39) 今, 武田：近世病理学総論，炤

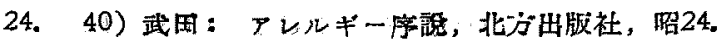

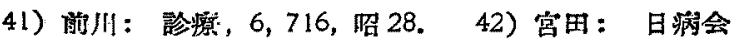

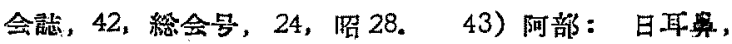

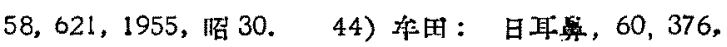

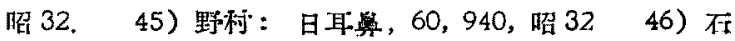

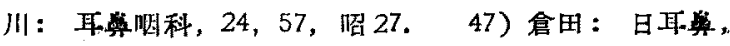

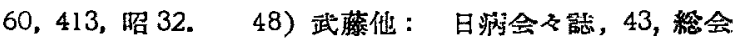

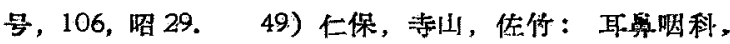
23，189，炤 26.50）二宫他：北関東医学，7，457, 1957. 51）大沢，村主，武石：遁信医学，9，829，嚾

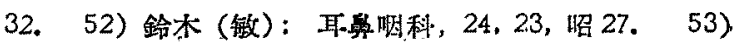

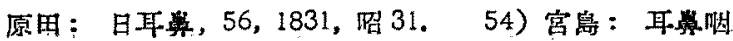
科，25，465，沿 28 ，55）域并：日耳莮，59，1691，昭 31.

擱筆に当り恩師鉿不教授ならびに第一纺理石 井教授の御指等，御校閵を深謝すると共に淔接 御指導御晭㩲をいたら゙いた大石助教授ならびに

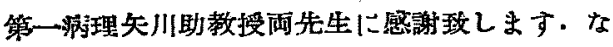
お終始御協力いたら゙いだ吉田，柴田，饭兽各比 に厚了御礼申し上げます・本論交要旨は第 24 回誩州地方会において発哜した。

（原稿到曾＝沿和 33.9 .8 日一急載） 